International Journal of Social Science And Human Research

ISSN(print): 2644-0679, ISSN(online): 2644-0695

Volume 04 Issue 11 November 2021

DOI: 10.47191/ijsshr/v4-i11-23, Impact factor-5.586

Page No: $3237-3242$

\title{
Managing Secondary Education for Functional Leadership, Values Re-Orientation and Sustainable National Development in Nigeria
}

\author{
Ofeimu, Josiah (Ph.D) ${ }^{1}$, Kolawole, Bolanle Oluwatoyin (Ph.D) ${ }^{2}$ \\ ${ }^{1,2}$ Department of Educational Foundations and Management, Faculty of Education, Ambrose Alli University,P.M.B. 14, Ekpoma, \\ Edo State, Nigeria
}

\begin{abstract}
The study examined the management of secondary education for functional leadership, values re-orientation and sustainable national development in Nigeria. The descriptive survey design was adopted. The population comprised 142 principals of public junior and senior secondary schools in Edo Central Senatorial District of Nigeria. The entire population was used. The questionnaire was used for data collection and was validated by experts. The test-re-test reliability method was used and a reliability coefficient of 0.76 was obtained. The mean and percentage were used for data analysis. The study found that corruption, poor funding, get-rich quick syndrome among the youths, cultism, poor management of resources by school administrators, poor quality of teaching staff, low quality leadership by school heads, teachers being poor role model, lack of parental support in the area of students' discipline and political instability were problems affecting management of the education system. It was recommended that the curriculum of the school should be re-adjusted and premium placed on values and dignity in hard work and that the quality of the teachers and instructors must be enhanced through in-service training.
\end{abstract}

KEYWORDS: Managing Education, Functional Leadership, Value Re-orientation and Sustainable National Development

\section{INTRODUCTION}

Education, all over the world, is generally regarded and recognized as the most effective apparatus for the understanding of situations, analysis of circumstances and participation in events for the purpose of development correction, advancement and sustainability (Meenyinikor, Chiemezie \& Ezekiel, 2013). Education is a veritable instrument for bringing about positive changes in the pattern of life of people. The school is a place where human beings are gathered for the purpose of teaching and learning. The school grooms and socializes students. This is in addition to its custodial role of cultural perpetuation. The destiny of the nation and individuals is shaped in the classrooms through education which is the process of human capital development that involves the transmitting of knowledge, skills and values to ensure proper intellectual growth and character building for selfreliance of the individuals and overall national transformation (Ayeni, 2014). This underscores the provision of access to functional education as a fundamental human right of all citizens as provided by the 1948 United Nations Human Rights Act; also a great value has been placed on quality assurance in education by the international community, as an emerging policy perspective in the contemporary world which emanated at the World Conference on Education for All led by UNESCO in Jomtien, Thailand, in 1990. Representatives of the international community (155 countries, as well as representatives from 150 organizations) agreed that all countries should pay greater attention towards improving all aspects of the quality of education and ensuring excellence of all. This is to ensure substantial achievement of recognized and measurable learning outcomes in schools, especially in literacy, numeracy and essential life skills (UNESCO, 2002).

The school is the only social institution where formal education is given to the young of the society and where they also learn about the ways of the society (Akindutire, 2014). Central to the actualization of the goals of the school system is the human factor that provides leadership in the schools. The absence of the right quality and quantity of the human resource in the school system goes a long way in affecting the educational services provided in the school system. In the secondary school system, for example, there are two categories of the human factor that render educational services. These are the teaching and the nonteaching staff. The value system in the school depends to a large extent, is influenced by the nature of leadership provided in such institution especially by the principal, who is the administrator. The achievement of secondary school goals depends on the ability of the principal to provide purposeful and directional leadership. 


\section{Managing Secondary Education for Functional Leadership, Values Re-Orientation and Sustainable National Development in Nigeria}

Leadership is the process of influencing the activities of a group of people by a leader in efforts towards goal achievement. It involves a force that initiates actions in people. It could be described as the ability to get things done with the assistance and co-operation of other people within the school system (Adeyemi, 2011). The leadership provided in the school setting determines to a large extent the attainment of the objectives of the system and the overall performance and value system. Yahaya (2014) stated that the problem of providing effective leadership in our schools cannot be treated in isolation without reference to what obtains in the Nigerian society. This is because schools exist in order to serve the society by transmitting its culture, norms and values to the younger generation who will be leaders of tomorrow. Unfortunately, the Nigerian society is now characterized by suicide bombing and killings, and kidnapping has become the order of the day. Elections in the country are occasions for anxiety because of the dangerous games that politicians play in order to win or steal electoral mandate. Such games include thuggery, rigging, kidnapping and other electoral malpractices, which generated serious crisis in which lives and properties are lost. Needless to say therefore that until there is value re-orientation in the leadership provided in schools, our dear country Nigeria may continue to experience backwardness and remain a dependent nation.

Value is defined as the importance, significance, worth or usefulness of an item that is real like stone or abstract like air. Value is a construct man places on an item. In this discuss, value is attached to usefulness of Secondary School Education in Nigeria. The positive development of any individual, group and society is a function of value outcomes. Education is a requirement for societal formation, societal change and transformation. It is a deliberate action that has power to add value to the life of its seekers and those who posses it. Education that is of value is education that has worth, power, strong, useful, desired, quality, important and desirable for its own sake (Magaji, 2014). It is education that combines both knowledge and skills, thereby making it education that is required for national development. Magaji further states that Value is the worth education offers to its learners and that it is the importance education gives to individuals, communities and societies. The importance is observed and measured in terms of economic growth, health improvement, and employment opportunities to graduates of the educational system, advancement of secondary school graduates to further studies in universities and other tertiary institutions and the general improvement in all aspects of life of the individuals, communities and larger societies. It also enables the individual to be self reliant and contribute meaningfully to national development.

Functional education is that which equips the learner with useful knowledge and skills that the learner can put into use when employed or for self employment and or creating jobs for others. Functional education makes the graduates productive. Productivities of these graduates count toward economic development of the nation. Functional education in its true meaning is a worthy activity that prepares an individual for useful life now and here and for the future. It is a good commodity for an individual, community and the general society. It is a weapon that helps those who are faithful and wants to equip themselves with it for better now and the future. It is a weapon for fighting the power of ignorance. Secondary School graduates in Nigeria are expected to exhibit some results of the worthy education received. True and honest men and women are the products of valuebased education.

Magaji (2014) identified the following as the importance of core value education:

i. Mold the behaviours of the youths to meet societal standards.

ii. Shape the future of individuals and society.

iii. Expose students to diversities and different points of views of other people.

iv. Have positive influence of peers on students conduct and achievement.

v. Provide variety of experiences through parents and community engagement in the schools, such as the Parents Teachers Associations (PTA) in primary and secondary schools and Parents Consultative Forum (PC) as in Babcock University, where parents and school administrator meet to share their valuable experiences and agree on which values be passed to the students for positive development.

vi. Give individual benefits that include acquisition of academic knowledge and skills.

vii. Introduce collective welfare of societies, institutions and freedoms to succeed and continue into the future.

viii. Equip graduates with knowledge and different skills that they would apply into diverse endeavours with the aim of developing themselves and the nation.

Oyetade and Oladiran (2012) note that the concept of sustainable development has been an age long discourse in all education matters. For education is a human development process, schools are one of the societal institutions that have an active role in helping children and youths learn to live and work in their nation. Hence, it is of great importance that teachers make their classroom places where children feel that their ideas will be given a respectful hearing, and where they know that learning will be placed upon them. There should be daily occasions to ask pupils what they think, how a proposed problem is to be solved, what features they think should be located on a class-constructed map, and so on. In such a classroom environment, the meaning of involvement is learned, and good will and mutual respect are observed and experienced. Since children learn what they live, and since we want children to learn the satisfactions of participatory approach, we should look for concrete ways in which pupils input 


\section{Managing Secondary Education for Functional Leadership, Values Re-Orientation and Sustainable National Development in Nigeria}

have a better-than-even chance of influencing policy. Where civic sensitivity and responsibility are nurtured, thus children tend to develop a feeling of loyalty and protectiveness towards their class. This sometimes expresses itself in surprising, rewarding ways.

The academic circle is bedeviled with corruption, poor funding, lack of infrastructure, leadership problem, violence, rape, sexual harassment, fraud, examination malpractice, cultism among others. These anti social behaviours have gradually reduced the value system in our education among the comity of nations. A society that has decidedly inverted its value system to call good evil and evil good is nothing better than a satanic world (Oyetade \& Oladiran, 2012). Oyetade and Oladiran further expressed that what has great moral premium and value quality in Nigeria today are: Wealth at all cost; End justifies the means; Steal and don't be caught; Plea-bargaining; Oppress the poor; Utilize your position to steal; Immorality, nudity, lying, cheating, killing and violence are the cherished norms. They further maintained that our value system has plummeted dangerously and only the loyal party men are good but objective, audacious party men are to be hunted down. Craze for power, "third termism" and craze for power social, moral, religious, political vices have been enthroned at the expense of their corresponding virtues. These societal vices have crept into the school system and the schools in turn give back same corrupt minded products thereby reducing further the cherished societal values.

Amanchukwu (2014) asserted that there should be a clarion call for various education stakeholders to develop curricular that will ameliorate the inconsistencies or anomalies faced in our present day teaching and learning. A new curriculum for the $21^{\text {st }}$ century is needs to be developed since things are changing around us rapidly and dramatically. As we can see the world is becoming more interconnected, the environment is becoming less stable and technology is continuously changing our relationship to information. Changing global conditions requires radical changes to match up with the challenges in the 21 st century. It is expected that the new curriculum must have advantage of digital technologies and help students become digitally literate (digital natives). Those of us in academia have discovered that schools no longer have monopoly on academic learning and if the faculty (lecturers) do not adapt, the world would simply leave them behind.

In our educational institutions, skill acquisition opportunities should be encouraged so as to make the Nigerian child selfemployed if he cannot get employed by the government establishments. Vocational and skill acquisition courses should be made affordable; and courses must be broken into smaller modules so that the students can study with flexibility. At the same time, educators must be qualified and willing to give valid carrier advice and that is why it is important to develop the developers so they can perform in their areas of specialty. Assessment of these students should be based on international standards and domestic needs. There is no need cutting corners since these students are being educated to compete with their counterparts in other developing and developed countries.

The drive towards re-engineering the process of teaching and learning civic education in our primary and secondary schools has become very imperative especially in the face of awakening national consciousness and promoting sustainable development. In the 80s, it became painful evident that lack of civic education and patriotic orientation had led to disorientation in schools and the larger society. The consequences were being felt at all strata of our society. Recent occurrences have indicated that Nigeria is on the brink of loosing its national development. The prevalent trend of corruption, indiscipline, disrespect for both elders and the rule of law, non committal to duty and so on are some of the manifestations of negative values in the Nigerian society replicated in the school system. This calls for urgent value re-orientation because of their far-reaching impact on sustainable development of Nigeria.

\section{STATEMENT OF THE PROBLEM}

The goal of secondary education according to the Federal Republic of Nigeria (2004) in its National Policy on Education is to prepare the individual for useful living within the society and for higher education. Section 1 sub-section 7(b \& d) of the policy document emphasis the national educational goals as the "inculcation of the of the right type of values and attitudes for the survival of the individual and the Nigerian society; and the acquisition of appropriate skills and the development of mental, physical and social abilities and competences as equipment for the individual to live in and contribute to the development of the society". By extension, secondary education is expected to create middle level manpower and a conscious social being who can contribute meaningful to the development of the society. Looking at the secondary education today in Nigeria, what is observed is corruption, ineptitude, moral decadence, poor infrastructure, neglect by government and show of incompetence by teachers. These social ills in the education sector are having ripple effect on the core value of the society and the development of the national economy. It becomes imminent therefore, to re-examine secondary education management in the context of leadership, value reorientation and sustainable development in Nigeria.

\section{RESEARCH QUESTIONS}

1. What are the challenges that hinder the effective management of secondary education for leadership reorientation and sustainable national development in Nigeria? 


\section{Managing Secondary Education for Functional Leadership, Values Re-Orientation and Sustainable National}

Development in Nigeria

2. What are the possible solutions for enhancing secondary education for value reorientation and sustainable development in Nigeria?

\section{METHODOLOGY}

Descriptive survey research design was employed for this study. This is because the opinion of the respondents was sought. The study was carried out in secondary schools in Edo Central Senatorial District of Nigeria. The population for the study comprises one hundred and forty-two (142) principals in the junior and senior public secondary schools in the senatorial district (source: Edo State Post Primary Education Board, Benin City, 2017). The researcher adopted no sampling technique, since the population is manageable and as such the 142 population was used. The instrument used to collect data was the questionnaire of modified four point scale with the following response mode, Strongly Agreed (SA), Agreed (A), Disagreed (D), Strongly Disagreed (SD) weighted 4, 3, 2, and 1 respectively for the two research questions. Validation of the instrument was done by two experts in the faculty of education of Ambrose Alli University, Ekpoma. The test-re-test reliability was used to determine the internal consistency of the items and a reliability index of 0.76 was obtained. The mean and percentage were used for data analysis.

\section{RESULTS}

Research Question 1: What are the challenges that hinder the effective management of secondary education for leadership, value re-orientation and sustainable national development in Nigeria?

\begin{tabular}{|l|l|l|l|l|l|}
\hline S/N & Item & $\begin{array}{l}\text { Strongly } \\
\text { Agreed }\end{array}$ & Agreed & Disagreed & $\begin{array}{l}\text { Strongly } \\
\text { Disagreed }\end{array}$ \\
\hline 1 & Corruption in the society & $80(56.3 \%)$ & $42(29.6 \%)$ & $12(8.5 \%)$ & $8(5.6 \%)$ \\
\hline 2 & Poor funding of the education sector & $78(54.9 \%)$ & $50(35.2 \%)$ & $6(4.2 \%)$ & $8(5.6 \%)$ \\
\hline 3 & Get-rich quick syndrome among the youths & $88(62 \%)$ & $32(22.5 \%)$ & $7(4.9 \%)$ & $15(10.6 \%)$ \\
\hline 4 & Cultism in the school system & $50(35.2 \%)$ & $40(28.2 \%)$ & $30(21.1 \%)$ & $22(15.5 \%)$ \\
\hline 5 & $\begin{array}{l}\text { Poor management of resources by school } \\
\text { administrators }\end{array}$ & $45(31.7 \%)$ & $38(26.8 \%)$ & $28(19.7 \%)$ & $31(21.8 \%)$ \\
\hline 6 & Poor quality of teaching staff & $41(28.8 \%)$ & $35(24.6 \%)$ & $40(28.2 \%)$ & $26(18.3 \%)$ \\
\hline 7 & Low quality leadership by school heads & $50(35.2 \%)$ & $32(22.5 \%)$ & $32(22.5 \%)$ & $28(19.7 \%)$ \\
\hline 8 & Teachers being poor role model & $55(38.7 \%)$ & $38(26.7 \%)$ & $30(21.1 \%)$ & $19(13.4 \%)$ \\
\hline 9 & $\begin{array}{l}\text { Lack of parental support in the area of } \\
\text { students' discipline }\end{array}$ & $45(31.7 \%)$ & $62(43.7 \%)$ & $21(14.8 \%)$ & $14(9.9 \%)$ \\
\hline 10 & Political instability & $60(42.3 \%)$ & $68(47.9 \%)$ & $10(7 \%)$ & $4(2.8 \%)$ \\
\hline
\end{tabular}

The result of this study showed that all the respondents agreed with all the items on the scale. This meant that the challenges that hinder the effective management of secondary education for leadership, value re-orientation and sustainable national development in Nigeria are corruption in the society, poor funding of the education sector, get-rich quick syndrome among the youths, cultism in the school system, poor management of resources by school administrators, poor quality of teaching staff, low quality leadership by school heads, teachers being poor role model, lack of parental support in the area of students' discipline and political instability.

Research Question 2: What are the possible solutions for enhancing secondary education for value reorientation and sustainable development in Nigeria?

\begin{tabular}{|c|c|c|c|c|c|}
\hline $\mathrm{S} / \mathrm{N}$ & Item & $\begin{array}{l}\text { Strongly } \\
\text { Agreed }\end{array}$ & Agreed & Disagreed & $\begin{array}{l}\text { Strongly } \\
\text { Disagreed }\end{array}$ \\
\hline 1 & $\begin{array}{l}\text { Provision of adequate and up-to-date } \\
\text { facilities and equipment in schools }\end{array}$ & $90(63.4 \%)$ & $45(31.7 \%)$ & $6(4.2 \%$ & $1(1 \%)$ \\
\hline 2 & $\begin{array}{l}\text { Placing less emphasis on paper qualification } \\
\text { but on practical expertise of candidates }\end{array}$ & $70(49.3 \%)$ & $35(24.6 \%)$ & $25(17.6 \%)$ & $12(8.5 \%)$ \\
\hline 3 & $\begin{array}{l}\text { Partnership between school heads and } \\
\text { communities in the leadership and } \\
\text { maintenance of school discipline }\end{array}$ & $55(38.7 \%)$ & $50(35.2 \%)$ & $28(19.7 \%)$ & $9(6.3 \%)$ \\
\hline 4 & $\begin{array}{l}\text { Changing the societal value orientation of } \\
\text { "not how far but how well". }\end{array}$ & $65(45.8 \%)$ & $50(35.2 \%)$ & $20(14.1 \%)$ & $7(4.9 \%)$ \\
\hline 5 & $\begin{array}{l}\text { Adequate funding of secondary education by } \\
\text { government }\end{array}$ & $80(56.3 \%)$ & $45(31.7 \%)$ & $10(7 \%)$ & $7(4.9 \%)$ \\
\hline 6 & $\begin{array}{l}\text { Stringent measures put in place by } \\
\text { government at eradicating corruption in all } \\
\text { sectors of the economic sector in Nigeria }\end{array}$ & $75(52.8 \%)$ & $60(42.3 \%)$ & $2(1.4 \%)$ & $2(1.4 \%)$ \\
\hline
\end{tabular}




\section{Managing Secondary Education for Functional Leadership, Values Re-Orientation and Sustainable National Development in Nigeria}

The table showed the mean and percentage analysis of the solutions to for enhancing secondary education for value reorientation and sustainable development in Nigeria. All the items on the scale were highly rated by the respondents as possible solutions to enhancing secondary education for value re-orientation. They include provision of adequate facilities, placing less emphasis on paper certificate, school-community partnership in management of school discipline, having a change on societal values, adequate funding of schools and eradication of corruption from the society.

\section{DISCUSSION}

The finding of this study showed that secondary education are faced with many challenges ranging from corruption, poor funding, get-rich quick syndrome among the youths, cultism, poor management of resources by school administrators, poor quality of teaching staff, low quality leadership by school heads, teachers being poor role model, lack of parental support in the area of students' discipline and political instability. This finding corroborates that of Yahaya (2012), Magaji (2014) and Oyetade and Oladiran (2012) who found that the societal craze and emphasis for wealth at all cost; end justifies the means; steal and don't be caught; immorality, nudity, lying, cheating, killing and violence are the cherished norms. They further maintained that our value system has plummeted dangerously and that poor infrastructure, lack of teaching equipment, corruption, poor management of resources among others.

The finding also showed that provision of adequate facilities, placing less emphasis on paper certificate, schoolcommunity partnership in management of school discipline, having a change on societal values, adequate funding of schools and eradication of corruption from the society are the possible measures of curbing the menaces. The finding of this study is in consonance with that of Adeyemi (2011) and Amanchukwu (2014) who showed that providing good leadership in schools, changing our value system and placing premium on hard work would go a long way in enhancing sustainable development of Nigeria.

\section{CONCLUSION}

Managing secondary education is important to realizing the over all aim of the education sector. Value re-orientation in education connotes a fall in value of secondary education in Nigeria. This could mean a decrease in the standard of education. The value secondary education was known for in this country and the expectation as stipulated in the National policy on education is not what it is today. The study had discovered a fall in the value system of education in Nigeria. The current rise in unemployment especially as it affects school leavers at secondary level is due to the loss of value in the education especially in bequeathing in the young ones the right knowledge and practical skills and moral attitudes to survive in the competitive world. Reintroduction of functional education that has values, provides knowledge and skills for national development is the only way that would make the nation grow. Managing functional education is a key therefore to sustainable national development in Nigeria.

\section{RECOMMENDATIONS}

Based on the findings of the study, the researchers recommend the following.

a. The curriculum of the school should be re-adjusted and premium placed on values and dignity in hard work. The young ones must be thought of the importance of maintaining good value systems of the society.

b. The quality of the teachers and instructors must be enhanced through in-service training. The teachers must wake up to their duty of care and role of in-loco-parentis.

c. There should be effective management of available resources by school administrators for the attainment of secondary school goals.

d. The mentality of individuals, communities and entire society that the success of a man is measured by the material possession should be discarded and re-oriented toward positive value.

e. Government and other stakeholders must fight corruption at all cost which has become a contagious disease eating the fabrics of the society.

\section{REFERENCES}

1) Adeyemi, T.O. (2011). Principals' leadership styles and teachers' job performance in senior secondary schools in Ondo state, Nigeria. Current Research Journal of Economic Theory, 3(3), 84-92.

2) Akindutire, J.O. (2014). Influence of principals' attitude to work on teachers' job performance of junior secondary schools in Edo Central Senatorial District, Nigeria. Thesis submitted to the school of postgraduate studies, Ambrose Alli University, Ekpoma.

3) Amanchukwu, R.N. (2014). Management of secondary education for sustainable living in a period of security challenges in Nigeria. Journal of Education and Practice, 5(19), 162-170. 
4) Ayeni, A.J. (2014). Principals and Parents Partnership for Sustainable Quality Assurance in Nigerian Secondary Schools. 4th International Conference on Education, Research and Innovation, 81(23), 140-155.

5) Federal Republic of Nigeria, (2004). National Policy on Education. NERDC: Abuja

6) Magaji, S. (2014). Value re-orientation in secondary school education in Nigeria. Knowledge Review, 29(1), 1-7.

7) Meenyinikor, J.N.D., Chiemezie, O.F. and Ezekiel, B.P. (2013). Secondary school administration and human capital development in Rivers State, Nigeria. African Educational Research Journal, 1(2), 64-71.

8) Oyetade, T. and Oladiran, A. (2012) Management of universal basic education scheme (U.B.E.) for qualitative education in Nigeria. Education, 129(2), 308-314.

9) UNESCO, Nigeria private sector and education for all. Abuja: UNESCO Publication. 2002. Pp.34-35.

10) Yahaya, H. (2014). The need for effective leadership in secondary schools and rebranding Nigeria. Department of Educational Foundations Sa'adatu Rimi College of Education Kumbotso, Kano, PP, 24-32. 